\title{
Experimental Infection of Laboratory Animals and Sheep with Gongylonema pulchrum in Japan
}

\author{
Noboru KUDO') ${ }^{1)}$ Tooru KONEGUCHI ${ }^{2)}$, Hiromi IKADAI ${ }^{1)}$ and Takashi OYAMADA ${ }^{1)}$ \\ ${ }^{1)}$ Department of Veterinary Parasitology, School of Veterinary Medicine and Animal Sciences, Kitasato University, Towada, Aomori 034- \\ 8628 and ${ }^{2}$ Mizusawa Livestock Hygiene Service Center, Mizusawa, Iwate 023-0003, Japan
}

(Received 12 December 2002/Accepted 8 April 2003)

ABSTRACT. Japanese White rabbits, Wistar rats, ddY mice, Suffolk sheep, and a domestic cat were each orally inoculated with $20-140$ third-stage larvae (L3) of Gongylonema pulchrum, isolated from naturally infected dung beetles captured in Aomori Prefecture. Worm recovery rates were $40.0-72.0 \%$ in rabbits at 7, 14, and 19 weeks post-infection (PI) and 3.3-25.0\% in rats at 19 weeks PI. Those in 2 sheep at 7 weeks PI showed $53.6 \%$ and $29.3 \%$. No worms were recovered from the mice and the cat. In the susceptible animals, many worms were found in the esophagus, and a few were present in the pharyngeal mucosa, tongue, buccal mucosa, and cardiac portion of the stomach wall. No distinct morphological differences were observed in the worms from rabbits and sheep. These results indicate that rabbits are very suitable experimental definitive hosts for G. pulchrum.

KEY WORDS: definitive host, experimental infection, Gongylonema pulchrum.

J. Vet. Med. Sci. 65(8): 921-925, 2003

Gongylonema pulchrum is a spiruroid nematode that occurs in the upper digestive tract of various mammals throughout the world. It has been reported in domestic and wild ruminants, equids, swine, primates, squirrels, rabbits, bears, skunks, hedgehogs, and occasionally in man [3]. In Japan, G. pulchrum has been found from cattle in Hokkaido and northern Honshu [7, 15], Japanese macaque (Macaca fuscata) in Kyushu [16], and sika deer (Cervus nippon) in Hyogo [17]. This nematode has an indirect life cycle, and many species of dung beetles serve as intermediate hosts. Eleven species of dung beetles were reported as intermediate hosts for this nematode in northern Honshu [8].

Experimentally, cattle, sheep, pigs, rabbits, guinea pigs, and rats were successfully infected with $G$. pulchrum $[2,10$, 14], and the encapsulated larvae were found in the tissues of internal organs in experimentally infected mice [13]. In these experiments, however, the numbers of animals used were small, and the rate of worm recovery was not determined in some animals. Therefore, the comparative susceptibility of mammalian hosts to G. pulchrum has not been ascertained. Furthermore, there is little information on the location of worms in these animals. Prior reports of Gongylonema infection in cattle indicate that the parasite caused chronic esophagitis and sometimes deformation of the esophagus [4]. Duncan et al. [5] reported that lingual gongylonemiasis in Goeldi's monkeys might have predisposed the animals to pasteurella septicemia, which resulted in their deaths. The distribution of worms within the definitive hosts is closely associated with the pathogenesis of the parasite. This paper presents further information on the experimental infections of laboratory animals and sheep with G. pulchrum in Japan.

Seven Japanese White rabbits (3-mo-old females), 6 Wistar rats (4-wk-old males), 3 ddY mice (4-wk-old males), 2 Suffolk sheep (10-11-mo-old males), and a domestic cat (adult male, age unknown) were each orally inoculated with
20-140 third-stage larvae (L3) of G. pulchrum. These larvae were isolated from naturally infected dung beetles ( $A p h$ odius spp. and Copris spp.) captured at Rokkasho, Aomori Prefecture where these beetles are frequently and heavily infected (Fig. 1). The inoculated animals were euthanized at 7,14 , or 19 weeks post-infection (PI), and their upper digestive tracts were examined for worms. The mucosae of the oral cavity, tongue, pharynx, esophagus, and stomach wall (or cardiac portion of rumen in sheep) were inspected under a dissecting microscope. Thereafter, the tissues were put into artificial gastric juice (pepsin, 1:10,000, $5 \mathrm{~g} ; \mathrm{HCl}, 5 \mathrm{ml}$ in $1,000 \mathrm{ml}$ water) and kept overnight at $37^{\circ} \mathrm{C}$ to recover the remaining worms. Furthermore, other visceral organs and muscle tissues of mice were fragmented with pointed forceps and examined by artificial digestion. The worms recovered from each animal were fixed in $10 \%$ hot formalin,

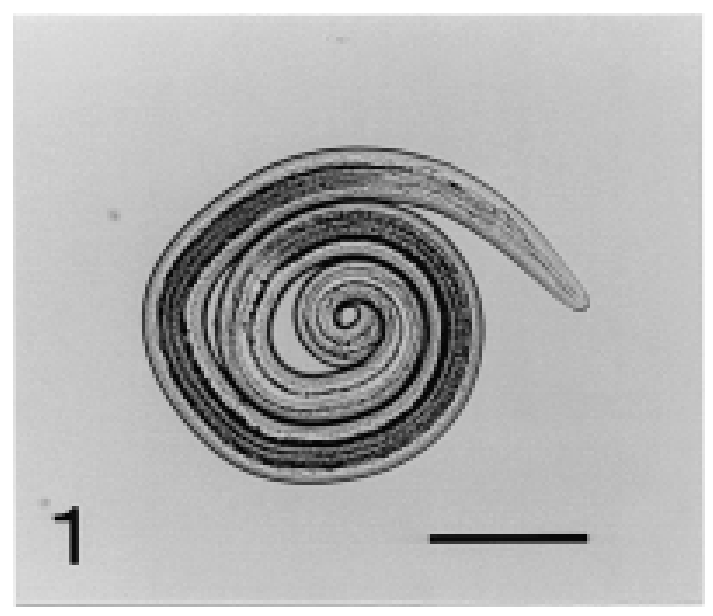

Fig. 1. Third-stage larva of Gongylonema pulchrum isolated from Aphodius sublimbatus. Bar $=0.2 \mathrm{~mm}$. 
Table 1. Experimental infection of laboratory animals and sheep with third-stage larvae of Gonylonema pulchrum

\begin{tabular}{|c|c|c|c|c|c|c|c|c|c|c|c|c|}
\hline \multirow{3}{*}{ Animals } & & \multirow{3}{*}{$\begin{array}{c}\text { Weeks } \\
\text { post- } \\
\text { infection }\end{array}$} & \multirow{3}{*}{$\begin{array}{l}\text { No. of } \\
\text { larvae } \\
\text { fed }\end{array}$} & \multirow{3}{*}{$\begin{array}{l}\text { Buccal } \\
\text { mucosa }\end{array}$} & \multicolumn{6}{|c|}{ No. of worms recovered from } & \multirow{3}{*}{ Total } & \multirow{3}{*}{$\begin{array}{l}\text { Worm } \\
\text { recovery } \\
\text { rate (\%) }\end{array}$} \\
\hline & & & & & \multirow[t]{2}{*}{ Tongue } & \multirow{2}{*}{$\begin{array}{c}\text { Pharyngeal } \\
\text { mucosa }\end{array}$} & \multicolumn{3}{|c|}{ Esophagus } & \multirow{2}{*}{$\begin{array}{c}\text { Cardiac } \\
\text { portion of } \\
\text { stomach wall }\end{array}$} & & \\
\hline & & & & & & & $\begin{array}{c}\text { upper } \\
\text { portion }\end{array}$ & $\begin{array}{l}\text { middle } \\
\text { portion }\end{array}$ & $\begin{array}{c}\text { lower } \\
\text { portion }\end{array}$ & & & \\
\hline \multirow{7}{*}{ Rabbit } & 1 & 7 & 50 & 0 & 0 & 5 & 9 & 14 & 6 & 0 & 34 & 68.0 \\
\hline & 2 & 7 & 50 & 4 & 0 & 0 & 16 & 11 & 4 & 0 & 35 & 70.0 \\
\hline & 3 & 14 & 100 & 1 & 2 & 0 & 19 & 12 & 6 & 0 & 40 & 40.0 \\
\hline & 4 & 19 & 50 & 0 & 0 & 0 & 13 & 10 & 13 & 0 & 36 & 72.0 \\
\hline & 5 & 19 & 50 & 0 & 0 & 0 & 11 & 12 & 9 & 0 & 32 & 64.0 \\
\hline & 6 & 19 & 100 & 0 & 0 & 17 & 15 & 11 & 13 & 0 & 56 & 56.0 \\
\hline & 7 & 19 & 100 & 0 & 0 & 0 & 23 & 20 & 2 & 0 & 45 & 45.0 \\
\hline \multirow[t]{6}{*}{ Rat } & 1 & 19 & 20 & 0 & 0 & 1 & 1 & 0 & 1 & 0 & 3 & 15.0 \\
\hline & 2 & 19 & 20 & 1 & 0 & 1 & 2 & 0 & 1 & 0 & 5 & 25.0 \\
\hline & 3 & 19 & 30 & 0 & 1 & 2 & 1 & 0 & 0 & 0 & 4 & 13.3 \\
\hline & 4 & 19 & 30 & 0 & 0 & 0 & 3 & 0 & 0 & 0 & 3 & 10.0 \\
\hline & 5 & 19 & 30 & 0 & 0 & 0 & 0 & 0 & 0 & 1 & 1 & 3.3 \\
\hline & 6 & 19 & 30 & 0 & 0 & 0 & 1 & 0 & 0 & 0 & 1 & 3.3 \\
\hline \multirow[t]{2}{*}{ Sheep } & 1 & 7 & 140 & 0 & 0 & 0 & 8 & 8 & 56 & $3^{\text {a) }}$ & 75 & 53.6 \\
\hline & 2 & 7 & 140 & 0 & 4 & 0 & 7 & 10 & 18 & $2^{\mathrm{a})}$ & 41 & 29.3 \\
\hline \multirow[t]{3}{*}{ Mouse } & 1 & 7 & 50 & 0 & 0 & 0 & 0 & 0 & 0 & 0 & 0 & - \\
\hline & 2 & 7 & 50 & 0 & 0 & 0 & 0 & 0 & 0 & 0 & 0 & - \\
\hline & 3 & 7 & 50 & 0 & 0 & 0 & 0 & 0 & 0 & 0 & 0 & - \\
\hline Cat & 1 & 19 & 100 & 0 & 0 & 0 & 0 & 0 & 0 & 0 & 0 & - \\
\hline
\end{tabular}

a) Cardiac portion of rumen.

cleared in a lactophenol solution, and observed using a camera lucida.

The recovery of worms from the experimentally infected animals is summarized in Table 1 . Worms were recovered from the rabbits, rats, and sheep but not from the mice and the cat. Worm recovery rates in rabbits were $40.0-72.0 \%$ (55.6\% on average) at $7-19$ weeks PI, and the rates showed a slight decrease when more larvae were fed. Similarly, the recovery rates in rats at 19 weeks PI were $3.3-25.0 \%$ $(10.6 \%)$, and those in 2 sheep at 7 weeks PI showed $53.6 \%$ and $29.3 \%$. The average rate of worm recovery in rats was significantly lower than that in rabbits at 19 weeks PI $(\mathrm{P}<0.01)$. According to Lucker [10], 103 mature worms $(89.6 \%)$ were recovered from one rabbit at 127 days PI when 115 L3 were inoculated, whereas only one male (2.9\%) was obtained from a rat at 167 days PI when 35 L3 were fed.

In the positive animals, many worms were found in the esophagus, and a few were present in the pharyngeal mucosa, tongue, buccal mucosa, and cardiac portion of the stomach wall. Lucker [10] and Popova [12] also noted that the worms were recovered mainly from the esophagus, and some of them were obtained from the tongue, palate, epiglottis, and pharynx in the experimentally infected rabbits and rats. In the present study, a more detailed distribution of worms in the esophagus was determined. The worms in rabbits were distributed widely to the esophagus, whereas those in rats and sheep were predominant in the upper or lower portion of the esophagus, respectively. Anwar et al. [1] reported that more worms were found in the lower portion than in the middle or upper portion of the esophagus in the naturally infected cattle. The present results with sheep are similar to those from their report. It suggests that the lower portion of the esophagus may be the most suitable site for $G$. pulchrum infection in ruminants.

At 7 weeks PI, most of the worms recovered from rabbits and sheep developed into young adults, but some of them were still juveniles: one fourth-stage larva (L4) from the buccal mucosa in one rabbit and one L3 and 7 L4 from the esophagus and cardiac portion of rumen in sheep. Fully developed worms were obtained from rabbits after 14 weeks PI and from rats at 19 weeks PI. According to Gupta [6], full development of $G$. pulchrum requires more than 50 days in rabbits.

Both mature and immature worms were found in the mucosa of the upper digestive canals, forming serpentine or entangled tracts (Figs. $2 \& 3$ ). The tracts with worms were slightly elevated, regularly or irregularly undulating, linear bulges. Empty tracts, which suggested migration of the worms, were also seen. They were less pronounced and flat. These macroscopic findings showed no differences among the susceptible animals.

The measurements of worms recovered from different animals are summarized in Tables $2 \& 3$. At 7 weeks PI, there were no distinct morphological differences between the worms from rabbits and sheep. The body lengths of worms from rabbits at 7 weeks PI were $24.8-32.1 \mathrm{~mm}$ in males and 42.5-55.3 $\mathrm{mm}$ in females, and those from sheep 

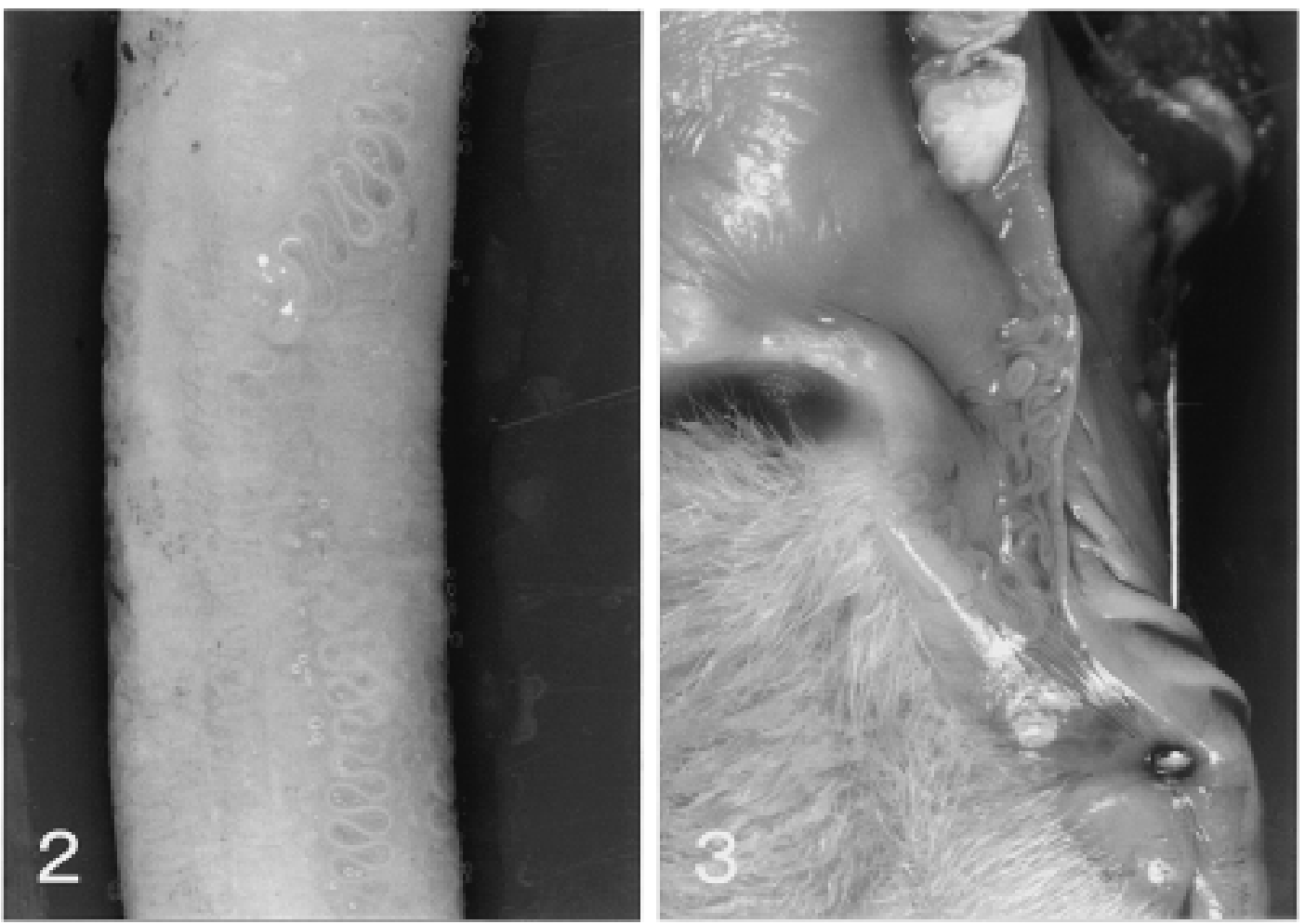

Figs. 2 \& 3.Esophagus (Fig.2) and oral cavity (Fig. 3) of a rabbit at 14 weeks PI, showing characteristic serpentine or entangled lesions in the mucosa.

Table 2. Measurements (mm) of Gonylonema pulchrum recovered from experimentally infected rabbits

\begin{tabular}{|c|c|c|c|c|}
\hline & \multicolumn{2}{|c|}{7 weeks post-infection } & \multicolumn{2}{|c|}{19 weeks post-infection } \\
\hline & $\begin{array}{c}\text { Male } \\
10 \text { specimens }\end{array}$ & $\begin{array}{c}\text { Female } \\
10\end{array}$ & $\begin{array}{c}\text { Male } \\
10\end{array}$ & $\begin{array}{c}\text { Female } \\
10\end{array}$ \\
\hline Body length & $24.8-32.1$ & $42.5-55.3$ & $25.0-40.9$ & $51.7-101.1$ \\
\hline Body width & $0.184-0.232$ & $0.216-0.272$ & $0.200-0.262$ & $0.280-0.400$ \\
\hline Length of pharynx & $0.044-0.064$ & $0.050-0.066$ & $0.046-0.064$ & $0.050-0.066$ \\
\hline \multicolumn{5}{|l|}{ Length of esophagus } \\
\hline Anterior portion & $0.416-0.544$ & $0.544-0.704$ & $0.424-0.560$ & $0.572-0.704$ \\
\hline Posterior portion & $3.26-4.14$ & $4.05-5.00$ & $3.35-4.83$ & $4.33-6.59$ \\
\hline Total length & $3.73-4.59$ & $4.59-5.64$ & $3.82-5.3$ & $4.91-7.18$ \\
\hline Cervical papillae ${ }^{a)}$ & $0.110-0.174$ & $0.140-0.204$ & $0.128-0.164$ & $0.152-0.228$ \\
\hline Nerve ring ${ }^{\text {a) }}$ & $0.240-0.296$ & $0.280-0.376$ & $0.244-0.292$ & $0.308-0.380$ \\
\hline Excretory pore ${ }^{\text {a) }}$ & $0.388-0.480$ & $0.520-0.656$ & $0.392-0.512$ & $0.560-0.728$ \\
\hline $\begin{array}{l}\text { Commencement of } \\
\text { cervical alae }^{\text {a) }}\end{array}$ & $0.160-0.202$ & $0.172-0.243$ & $0.170-0.202$ & $0.191-0.275$ \\
\hline \multicolumn{5}{|l|}{ Length of spicule } \\
\hline Left & $13.2-18.1$ & & $12.7-17.0$ & \\
\hline Right & $0.120-0.158$ & & $0.110-0.146$ & \\
\hline Length of gubernaculum & $0.094-0.130$ & & $0.094-0.126$ & \\
\hline Length of tail & $0.200-0.255$ & $0.186-0.279$ & $0.218-0.282$ & $0.176-0.302$ \\
\hline Vulva ${ }^{\text {b) }}$ & & $1.81-3.28$ & & $1.95-4.77$ \\
\hline
\end{tabular}

a) From anterior end, b) From posterior end.

were $22.3-30.4 \mathrm{~mm}$ and $40.4-51.6 \mathrm{~mm}$, respectively. On the other hand, the worms from rats at 19 weeks PI were significantly smaller than those from rabbits $(\mathrm{P}<0.01)$. The body lengths of worms from rabbits at 19 weeks PI were
$25.0-40.9 \mathrm{~mm}$ in males and $51.7-101.1 \mathrm{~mm}$ in females, whereas those from rats were $11.7-18.0 \mathrm{~mm}$ and 16.6-27.7 $\mathrm{mm}$, respectively. However, the ratios of the left spicule length/body length and distance from posterior end to vulva/ 
Table 3. Measurements (mm) of Gongylonema pulchrum recovered from experimentally infected sheep and rats

\begin{tabular}{|c|c|c|c|c|}
\hline & \multicolumn{2}{|c|}{$\begin{array}{c}\text { Sheep } \\
7 \text { weeks post-infection }\end{array}$} & \multicolumn{2}{|c|}{$\begin{array}{c}\text { Rat } \\
19 \text { weeks post-infection }\end{array}$} \\
\hline & $\begin{array}{c}\text { Male } \\
10 \text { specimens }\end{array}$ & $\begin{array}{c}\text { Female } \\
10\end{array}$ & $\begin{array}{c}\text { Male } \\
5\end{array}$ & $\begin{array}{c}\text { Female } \\
3\end{array}$ \\
\hline Body length & $22.3-30.4$ & $40.4-51.6$ & $11.7-18.0$ & $16.6-27.7$ \\
\hline Body width & $0.160-0.192$ & $0.208-0.244$ & $0.140-0.172$ & $0.160-0.236$ \\
\hline Length of pharynx & $0.044-0.058$ & $0.052-0.068$ & $0.040-0.054$ & $0.046-0.056$ \\
\hline \multicolumn{5}{|l|}{ Length of esophagus } \\
\hline Anterior portion & $0.456-0.536$ & $0.552-0.656$ & $0.324-0.448$ & $0.376-0.448$ \\
\hline Posterior portion & $3.09-3.59$ & $3.83-4.60$ & $2.75-3.19$ & $3.12-3.79$ \\
\hline Total length & $3.59-4.05$ & $4.46-5.23$ & $3.09-3.59$ & $3.50-4.23$ \\
\hline Cervical papillae ${ }^{\text {a) }}$ & $0.134-0.176$ & $0.162-0.196$ & $0.114-0.160$ & $0.136-0.140$ \\
\hline Nerve ringa) & $0.264-0.296$ & $0.308-0.360$ & $0.212-0.232$ & $0.232-0.268$ \\
\hline Excretory pore ${ }^{a)}$ & $0.424-0.512$ & $0.544-0.648$ & $0.312-0.384$ & $0.376-0.440$ \\
\hline $\begin{array}{l}\text { Commencement of } \\
\text { cervical alae }^{\text {a) }}\end{array}$ & $0.163-0.209$ & $0.216-0.243$ & $0.164-0.177$ & $0.172-0.184$ \\
\hline \multicolumn{5}{|l|}{ Length of spicule } \\
\hline Left & $11.2-15.2$ & & $5.0-8.8$ & \\
\hline Right & $0.142-0.174$ & & $0.104-0.118$ & \\
\hline Length of gubernaculum & $0.100-0.138$ & & $0.080-0.092$ & \\
\hline Length of tail & $0.191-0.227$ & $0.209-0.279$ & $0.155-0.200$ & $0.136-0.163$ \\
\hline Vulva $^{\text {b) }}$ & & $1.86-2.98$ & & $0.87-1.28$ \\
\hline
\end{tabular}

a) From anterior end, b) From posterior end.

body length showed a close resemblance in the worms from rabbits and rats. The former ratio was 0.48 (in average) for both animals, and the latter was 0.047 for rabbits and 0.050 for rats. It is well known that the mature G. pulchrum specimens from different hosts differ greatly in size. Lichtenfels [9] noted that both males and females from cattle, sheep, and deer were larger than those from pig, rat, rabbit, guinea pig, and man, while some morphometric characteristics, including the left spicule length/total body length, showed relatively little variation among those animals. In the present result, the size of worms from rabbits at 19 weeks PI was quite similar to that from naturally infected cattle. The body lengths of worms from cattle were $24.1-52.4 \mathrm{~mm}$ in males and $46.0-111.5 \mathrm{~mm}$ in females in our previous study [7]. These findings suggest that rabbits, as well as ruminants, may be suitable definitive host for G. pulchrum. In contrast, a rat is thought to be less suitable than a rabbit because of the recovery of smaller-sized and non-gravid worms from rats. At 19 weeks PI, all the female worms from rabbits contained many eggs in their uteri, but only a few worms in rats possessed intrauterine eggs.

In mice, no worms were recovered from any tissue at 7 weeks PI, although Ramishvili [13] noted encapsulated larvae in the tissues of internal organs of experimentally infected mice at 13 days PI. Therefore, we performed an additional examination to determine whether or not mice act as reservoir hosts for G. pulchrum. Five ICR mice (7-14wk-old males) were each orally inoculated with $50 \mathrm{~L} 3$ of $G$. pulchrum and examined for larvae in the same manner described above. As a result, 50, 39, and 7 larvae were recovered from mice at 2,5 , and 10 days PI, respectively, and none were recovered from the animals at 20 and 30 days PI. At 2 days PI, all 50 larvae were found in the proventricular portion of the stomach wall, and they were still alive. On the other hand, the larvae obtained at 5 and 10 days PI were located more widely within the upper digestive tract, such as the esophagus, tongue, buccal mucosa, and other tissues of the head, in addition to the proventricular portion of the stomach. Many larvae from these tissues were clearly damaged. The percentage of degenerated and dead worms was $28.2 \%$ at 5 days PI and $100 \%$ at 10 days PI. These results suggested that mice might not be very suitable reservoir hosts of G. pulchrum. In addition to the mice, a domestic cat was unsuccessfully infected with G. pulchrum; however, a report of a domestic cat in Czechoslovakia indicates that an infection with this nematode occurred naturally [11]. Further studies are necessary to assess the susceptibility of cats to G. pulchrum infection.

In conclusion, the high recovery rate and morphological findings of worms in experimentally infected rabbits suggest that the animals are very suitable experimental definitive hosts for G. pulchrum. In addition, the distribution of worms along the upper digestive tract, extending from the oral cavity to the lower portion of the esophagus in rabbits, was ascertained. A heavy infection of $G$. pulchrum may cause deformation of the esophagus and inflammation of the tongue, as mentioned above. In many human cases, the worms were found in the buccal mucosa [3]. The experimental infection of this nematode using rabbits is thought to be very useful in studying the pathogenesis, diagnosis, and therapeutics of gongylonemiasis in man and animals. 


\section{REFERENCES}

1. Anwar, M., Rak, H. and Gyorkos, T. W. 1979. Vet. Parasitol. 5: 271-274.

2. Baylis, H. A., Sheather, A. L. and Andrews, W. H. 1926. J. Trop. Med. Hyg. 29: 194-196.

3. Cappucci, D. T. Jr., Augsburg, J. K. and Klinck, P. C. 1982. pp. 181-192. In: Handbook Series in Zoonoses Section C: Parasitic Zoonoses, vol. 2 (Steele, J. H. ed.), CRC Press, Florida.

4. Čebotarev, R. S. and Poliščuk, V. P. 1959. Acta Parasitol. Pol. 7: $549-559$.

5. Duncan, M., Tell, L., Gardiner, C. H. and Montali, R. J. 1995. J. Zoo Wildlife Med. 26: 102-108.

6. Gupta, V. P. 1970. Curr. Sci. 39: 237-238.

7. Kudo, N., Oyamada, T. and Ito, K. 1992. Jpn. J. Parasitol. 41: 266-273 (in Japanese with English abstract).

8. Kudo, N., Oyamada, T., Okutsu, M. and Kinoshita, M. 1996. Jpn. J. Parasitol. 45: 222-229 (in Japanese with English abstract).

9. Lichtenfels, J. R. 1971. J. Parasitol. 57: 348-355.

10. Lucker, J. T. 1932. J. Parasitol. 19: 134-141.

11. Mituch, J. 1968. Folia Vet. 12: 165 (in German).

12. Popova, Z. G. 1959. Nauchn. Tr. Ukr. Nauchno-Issled. Inst. Eksp. Vet. 25: 19-30 (in Russian).

13. Ramishvili, N. D. 1973. Parazitol. Sb. 3: 112-136 (in Russian with English summary).

14. Ransom, B. H. and Hall, M. C. 1915. J. Parasitol. 2: 80-86.

15. Suzuki, K., Nakamura, K., Takahashi, K. and Seki, N. 1992. J. Jpn. Vet. Med. Assoc. 45: 120-124 (in Japanese with English summary).

16. Uni, S., Abe, M., Harada, K., Kaneda, K., Kimata, I., Abdelmaksoud, N. M., Takahashi, K., Miyashita, M. and Iseki, M. 1992. Ann. Parasitol. Hum. Comp. 67: 221-223.

17. Yokohata, Y. and Suzuki, Y. 1993. Jpn. J. Parasitol. 42: 440444. 